\title{
THE RELATIONSHIP BETWEEN PSYCHOLOGICAL EMPOWERMENT AND PSYCHOLOGICAL WELL BEING: THE ROLE OF SELF-EFFICACY PERCEPTION AND SOCIAL SUPPORT
}

\author{
Seçil BAL TAŞTAN ${ }^{1}$ \\ ${ }^{I}$ Marmara Üniversitesi, İşletme Fakültesi, Öğretim Görevlisi, Dr.
}

\begin{abstract}
THE RELATIONSHIP BETWEEN PSYCHOLOGICAL EMPOWERMENT AND PSYCHOLOGICAL WELL BEING: THE ROLE OF SELF-EFFICACY PERCEPTION AND SOCIAL SUPPORT
\end{abstract}

\begin{abstract}
The objective of this study is to examine the relationship between psychological empowerment and psychological well being. Additionally, it is aimed to find evidences about the mediating role of individuals' self-efficacy perception and the moderating role of perceived supervisor social support on the relationship between psychological empowerment and psychological well-being at work. The effect of psychological empowerment on work-related psychological well-being and the roles of self-efficacy and social support were examined through a structured research survey which has been performed among teaching staff working in public primary schools in Istanbul-Kadık̈y. The hypotheses were generated and empirically tested by the data obtained from the participants. The results have demonstrated that all four dimensions of the psychological empowerment had significantly positive relationships with psychological wellbeing states of the individuals. Moreover, the statistical findings have revealed that self-efficacy perception had a partial mediating role and perceived social support had a significant moderating role on the relationship between psychological empowerment and well-being. Furthermore, the findings of this study have provided insights to various public and private organizations from different sectors which aim to enhance psychological well-being of the individuals and try to improve their work-related positive affections at the workplace.
\end{abstract}

Keywords: Psychological Empowerment, Psychological WellBeing, Self-Efficacy, Social Support, Affective Work Perceptions of Teachers

\section{INTRODUCTION}

Psychological empowerment has received increasing attention within education sector, particularly within school teachers, and has been promoted as a state that will both facilitate change and increase job satisfaction, job commitment and well-being within teachers working in schools e.g. [1],[2]. A substantial body of literature has demonstrated links between psychological empowerment and a range of work outcomes particularly job satisfaction and well-being [3],[4],[5]. However, little is known about the
PSIKOLOJIK GÜÇLENDİRME ALGISI VE PSÍKOLOJIKK IYI HISSETME HALI ARASINDAKI ILISSKI: ÖZYETERLILIK ALGISI VE SOSYAL DESTEK ALGISININ ROL $\ddot{U}$

Özet: Bu çalıșmanın amacı, bireylerin psikolojik güçlendirme algısı ile işle ilgili iyi hissetme hali arasındaki ilişkiyi incelemektir. Bununla birlikte çalışmanın amacı, işyerinde psikolojik güçlendirme algısı ile psikolojik iyi hissetme hali arasındaki ilișkide bireylerin öz-yeterlilik inancının ara değişken rolüne ve sosyal destek algısının düzenleyici değişken rolüne ilişkin bulgular elde edebilmektir. Bu bağlamda, psikolojik güçlendirme algısı ve iyi hissetme hali arasındaki ilişkiyi ve algılanan öz-yeterlilik duygusu ve sosyal desteğin rolünü incelemeye yönelik tasarlanan yapılandırılmış saha araştırması, Istanbul ili Kadıköy ilçesine bağlı devlet ilköğretim okullarında görev yapmakta olan öğretmenler üzerinde uygulanmıștır. Araștırma modelinde ön görüllen bir dizi hipotez, katulimcilardan elde edilen ampirik verilere dayanarak test edilmiștir. Araștırma sonuçları, psikolojik güçlendirme algısının dört boyutunun da psikolojik iyi hissetme hali ile pozitif ve anlamlı şekilde ilişsili olduğunu göstermiştir. Bununla birlikte, elde edilen istatistiksel bulgulara gore, bireylerin öz-yeterlilik algısının psikolojik güçlendirme ve iyi hissetme hali arasındaki ilişkide kısmi seviyede ara değişken rolüne sahip olduğu ve amir sosyal desteğinin bu ilişkide düzenleyici bir etkiye sahip olduğu görülmüştür. Bütün bu sonuçlar, çalışanlarının işyerindeki psikolojik iyi hissetme halini ve çalışma yaşamıyla ilgili olumlu duygulanımlarını güçlendirmeyi amaçlayan ve farklı sektörlerde yer alan özel ve kamu kurumlarına bakış açısı sunmaya yardımcı olmaktadır.

Anahtar Kelimeler: Psikolojik Güçlendirme Algısı, Psikolojik İy Hissetme Hali, Esenlik, Öz-Yeterlilik Algısı, Sosyal Destek, Öğretmenlerin Çalışma Yaşamındaki Duygusal Algılamaları

psychological mechanisms through which this relationship occurs. Self-efficacy, or the individual's confidence in their ability to do the job, is the possible mechanism explored here. Additionally, the perception of social support is considered as another possible variable which could be influential within that supposed relationship. It is hypothesized that psychological empowerment perception may exert its influence through individuals' appraisals of themselves (self-efficacy) or their perceived social support from their colleagues or administration. This study aims to explore the relative contribution of self-efficacy and social support in 
explaining the relationship between psychological empowerment and well-being.

\section{BACKGROUND}

\section{II.1. Psychological Empowerment}

This study focuses on empowerment as a psychological construct which has received comparatively less attention than the structural perspective on empowerment. The term "empowerment" involves a wide range of concepts. Herrenkohl, Judson and Heffner [6] indicated some of the current uses of the concept such as redistribution of power and authority [7]. As further, the concept was described as maximizing employee contribution to the success of the organization and full participation of employees in decision making [8]; shared vision between employees and management [9]; and selfmotivation [10].

The psychological approach focuses on intrinsic motivation rather than on managerial practices used to increase individuals' levels of power. Empowerment is conceptualized, here, as a mind-set that employees have about their organization, rather than as something that management does to employees [11]. It is argued, within this framework, that empowerment involves "a subjective state of mind where an employee perceives that he or she is exercising efficacious control over meaningful work" [12]. Psychological empowerment, in this instance, depends on the creation of conditions appropriate for "heightening motivation for task accomplishment through the development of a strong sense of personal efficacy" [13].

Moreover, contemporary research on psychological empowerment has focused on articulating the empowerment process and the psychological underpinnings of the construct in terms of self-efficacy and autonomy [13]; [14]; [15]; [16]; [17]; [18]. To conceptualize empowerment in motivational terms, Bandura's [19] notion of self-efficacy is studied and advanced. With that sense, empowerment refers to a process that an individual's belief in his or her selfefficacy is enhanced [13].

In accordance with expectancy theory, an individual's motivation to increase his or her effort in a given task would depend on expectations concerning effort leading to the desired performance and that desired performance would lead to desired outcomes. Thus, empowerment as an enabling process affects both initiation and persistence of individuals' task behaviour [20]. With that respect, Conger and Kanungo [13] defined empowerment as the motivational concept of selfefficacy. Thomas and Velthouse [17] argued that empowerment is a multi-faceted construct. They defined empowerment more broadly as increased intrinsic task motivation manifested in a set of four cognitions reflecting an individual's orientation to the work role: meaning, competence, self-determination and impact. For a complete discussion of the terms, this study refers to Spreitzer [14] and Thomas and Velthouse [17].

The most current and widely used conceptualization of psychological empowerment is provided by Spreitzer [14], Spreitzer et al. [16], Spreitzer, De Janasz and Quinn [21] and is defined as "a motivational construct identified in four cognitions: meaning; competence; self-determination; and impact" [14]. Fundamentally, Spreitzer's conceptualization and measurement of psychological empowerment was based on Thomas and Velthouse's [17] identification of four cognitions believed to measure psychological empowerment. Within four cognitions; meaning (fit between the job task and one's own beliefs, values, and behaviors); competence (belief in one's ability to perform a job well); self-determination (feeling like one has control over one's work); and choice or what Spreitzer refers to as impact (feeling one can affect one's work outcomes) [22]; [21]; [17]; [23].

With that respect, it can be mentioned that psychological empowerment relates to how competent or capable individuals feel in an empowered work environment. Those who feel more competent about their ability to perform their work successfully should feel more satisfied with their work; be more affectively committed to their organization; have lower intentions to quit the organization; and demonstrate more positive work performance than those with lower levels of psychological empowerment. [23]

Alternatively, research based in a psychological/cognitive framework has provided suggestions that empowerment characterizes an individual's relationship with an organization, may impact a sense of connectedness, may affect decisions to continue or discontinue membership in that organization, and may influence several psychological states and attitudes. [11]. As further, in the literature, psychological empowerment research has been extended to the consequences of the psychological empowerment of individuals at the workplace [24]; [25]; [26]; [27]; [14]; [6]. Conger and Kanungo [13] implied that psychological empowering experiences led to an increase in "both initiation and persistence of individuals' task behavior". Furthermore, previous research has found psychological empowerment perceptions to be associated with increased job satisfaction [28], increased work effectiveness [29]; [26], increased in-role and extra-role performance behaviors [30], psychological well being [31], organizational commitment [23]; [11], decreased intentions to leave the organization [18], etc.

Therefore, in this study, it is attempted to examine the question of how psychological empowerment may affect teachers' state of psychological well being in the school. The purpose of this study is to examine the consequence of psychological empowerment on an important individual outcome; specifically psychological well being. 


\section{II.2. Psychological Well Being}

Psychological well being has also been shown to be an important outcome of psychological empowerment [31]; [32]. Individual in the working life have always tried to find out how a good life can be achieved and associated it with well-being and happiness. The concept of "wellbeing" is used as a general mental health term in the literature of psychology [33]; [34]; [35]; [36].

It is grouped into two as subjective and psychological well-being and also mentioned that it can be considered to be a multidimensional construct including both subjective and psychological well-being [37]. While subjective well being means happiness, relaxation and a relative absence of problems, psychological well being is usually described as taking on challenges and making efforts for personal development and growth. Moreover, [38] made important contributions to the studies on a good life, psychological well being and Ryff's [38] approach involved life purposes, awareness of individual potential and the quality of interpersonal relations. Eldeleklioğlu et al. [36] have implied that the model of well-being has a literature basis including the concepts such as self-realization, the fully functioning person, maturity and individualization.

As it is seen, well-being is a many-faceted concept, but its primary indicator is its affective level and quality, in terms of positive affect (e.g., feelings of happiness, satisfaction, high self-esteem) and feelings of distress (e.g., anxiety, depression, sense of hopelessness) [39]; [40]. Affect refers to mental states in which persons feel good or bad about what is happening to them. As described in terms of short-term emotions (e.g., sad, happy, enthusiastic), affect is transitory and situation specific [41]. The model to describe affect consists of two dimensions - pleasure and activation [42]. The pleasure dimension defines the level of subjective experience how well one is feeling, whereas the activation axis refers to a sense of mobilization of energy.

In this context, psychological well being consists of six psychological dimensions. Keyes, Shmotkin and Ryff [43] have explained them as follows: Selfacceptance is being satisfied and happy with yourself even if you are aware of your limits and having positive feelings about your past. Positive relations with others is developing and maintaining close relationships with different people, empathizing and caring about their happiness. Environmental control is shaping the environment and taking the opportunities to meet personal needs. Autonomy is the efforts to have individuality in the social environment and developing thoughts and codes of behavior according to personal standards in spite of social pressure. Life purposes is having aims in life and seeing a meaning in it. Personal development is being aware of your capacity, making efforts to improve your skills and being open to new experiences. As further, it is indicated that individuals' perceptions of autonomy and competence are associated with higher motivation, performance, and well-being. [44]

With that respect, the psychological well being concept is found meaningful to examine in order to understand its association with psychological empowerment construct. The meaning dimension of empowerment is important for psychological well being and job satisfaction, as an individual can only derive well being state and satisfaction from their work when engaged in a meaningful job [16]. Spreitzer et al. [16] also found the self-determination dimension of empowerment to be related to work satisfaction, suggesting that selfdetermination is a psychological need and a key component of intrinsic motivation. In terms of the impact dimension of empowerment, Liden et al. [24] and McClaine [31] argued that when individuals feel that their work can influence outcomes that affect their organization, they tend to feel more involved and therefore gain a sense of satisfaction with their job and psychological well being. Concerning the competence dimension of empowerment and job satisfaction, it is implied that individuals who feel more competent in their jobs are also likely to feel more satisfied with their jobs [16] and fell more psychological well being [45]; [32].

Thus, based on the above arguments indicating the relationship between psychological empowerment and psychological well being, the following hypothesis is offered:

H1. Psychological empowerment will correlate positively with psychological well being.

\section{II.3. Self-Efficacy}

Self-efficacy, derived from Bandura's [46] sociocognitive model, refers to one's belief about his or her ability and capacity to accomplish a task or cope with environmental demands. Within the work context, selfefficacy is usually measured as one's self-evaluation of their ability to cope with work demands; given the resources they possess [46]. With that sense, those with high self-efficacy are more likely to undertake a proactive approach when faced with stressful situations at work and carry out a broader set of role responsibilities than those with low self-efficacy [47]; [48]; [49]. Self- efficacy beliefs also play a major role in psychological and physical health outcomes. For example, those with high self-efficacy are more likely to report lower levels of perceived stress, and high self-efficacy has been shown to influence the physiologic stress response, which exerts direct influence on a variety of health outcomes such as blood pressure rates and cardiovascular heart disease [50]. Within the occupational literature, low self-efficacy is related to high levels of depression and anxiety [51], and high self-efficacy predicts job satisfaction and psychological well being and moderates the relationship between work-related stress and well-being [52]; [53]; [49] within different occupational contexts. For instance, 
high self-efficacy has been shown to be related to higher job satisfaction and lower turnover intentions [54] and higher in-role and extra-role performance behaviors among nurses [30].

Furthermore, Bandura [55] indicated that supportive relationships can enhance self-efficacy through modeling attitudes and strategies for managing problems, and providing resources for coping. In line with this, associations have been found between psychological empowerment, social support, self-efficacy perception and psychological well being [56]; [18]; [49]; [57]. Importantly, self-efficacy is reported to mediate the relationship between psychological empowerment and work outcomes such as job satisfaction, organizational commitment and well being [58]; [59]; [25]; [60].

With that respect, Social Cognitive Theory supports a model of interactive agency [19] and according to this theory; individuals are neither autonomous agents nor simply mechanical conveyers of environmental influences. Rather, they make a causal contribution to their own motivation and action. In this model of reciprocal causation; action, cognitive, affective, and other personal factors, and environmental events all operate as interacting determinants. Therefore, any account of the determinants of human action should include self-generated influences as a contributing factor [19]. This theoretical framework of efficacy can also be applied to psychological empowerment and psychological well-being.

Thus, based on the arguments of self-efficacy concept indicating its association with psychological empowerment and psychological well being, the following hypothesis is suggested:

H2. The relationship between psychological empowerment and psychological well being is mediated by individuals' self-efficacy perception.

\section{II.4. Social Support}

Supervisory social support includes a variety of behaviors by which a manager shows consideration, acceptance and concern for the needs and feelings of other people. Spreitzer [15] claims that individuals who perceive that they have high levels of socio-political support (e.g. from their immediate supervisor) report higher levels of empowerment than do individuals who perceive low levels of support. This support enhances a sense of personal power, which is manifested in enhanced feelings of both self-determination and impact [15] Lawler [56] further emphasizes the importance of supervisory social support, explaining how "good leadership gives people direction, energy and a sense of competence - that means empowerment". Moreover, according to Bandura [19], "individuals who are persuaded verbally that they possess the capabilities to master given tasks are likely to mobilize greater sustained effort than if they harbor self-doubts and dwell on personal deficiencies when difficulties arise', Menon [61] found that "consulting, recognizing, inspiring and mentoring behaviors of (an) immediate supervisor lead to greater perceived control and greater empowerment".

Moreover, according to Self-Determination Theory [62] work contexts which support psychological autonomy increase intrinsic motivation [63]. For instance, proper feedback enhances learning, thereby increasing job competence, whereas decision latitude and social support satisfy the need for autonomy and the need to belong, respectively. Additionally, Deci and Ryan [44] have emphasized that the fulfillment of extrinsic needs and social support needs specify the necessary conditions for psychological growth, integrity, and well-being. They have discussed this concept of external recognition and support needs by underlying its association with effective functioning, quality of behavior, mental health, satisfaction and psychological well-being. As further, Deci and Ryan [44] have implied that social interaction contexts which support individuals facilitate natural growth processes including both intrinsic and extrinsic motivations.

With that respect, it is recognized that there are evidences in the literature about the relationship between psychological well-being and social support [64]; [65]; [38]; [66]. The related studies have indicated that there are associations among social support, teaching and academic performance and personal outcomes [67]; [68]; [69]; [37]; [36]. Therefore, it is suggested that social support perception could be positively related with psychological well-being. However, although the concept of social support is expected to explain psychological well being, in this study, it is supposed that social support does not explain psychological well-being fully. That means, the perceived social support would not be the core of explaining well being but would moderate the relationship between psychological empowerment and psychological well being. Therefore, one of the aims of this study is to investigate the psychological well-being levels of teachers in terms of psychological empowerment with the moderating role of social support perception.

Based on the implications of social support concept's association with psychological empowerment and psychological well being, the following hypothesis is offered:

H3. The relationship between psychological empowerment and psychological well being is moderated by individuals' social support perception. (The positive association between psychological empowerment and psychological well being will be stronger with high levels of supervisory social support than with low levels of supervisory support)

\section{II.5. Mediational Interference}

As Mathieu and Taylor [70] implied, it is essential to clarify which type of mediational inference is tested in 
the research study. It is agreed that three types of meditational interference should be identified [70]; [49]: (a) indirect effects, where no direct relationship exists between the independent and the dependent variable, (b) partial mediation, where a direct relationship is present together with the mediated effect, and (c) a fully mediated model, where the previously direct relationship no longer exists after the mediator is introduced into the model.

As the relationships between psychological empowerment and psychological well-being have been confirmed previously, we propose one another mechanism to be present in our model: that psychological empowerment will be associated with the way in which individuals' perceived self-efficacy. This perception would, in turn, be associated with individuals' self-reports of psychological well-being.

\section{II.6. The Moderating Effect of Social Support on Well-Being and Psychological Empowerment}

It is recognized that there has been little research on the moderating effect of supervisory social support on the relationship between psychological empowerment and psychological well being. The previous research has demonstrated that psychological empowerment is a predictor of job satisfaction and well being perception of individuals [26].

As further, empirical findings have indicated that the role of social support is crucial in high-involvement management - the supervisor listening to subordinates and engaging in meaningful dialogue, minimizing subordinates feeling left out and being mistreated [56]; [71]; [13]. The results of a research study have revealed that only those individuals who felt that their supervisors were supportive reported that the social support intervention significantly increased their perceptions of work control and unit performance, affected their work attitudes, and improved their positive behaviors in the workplace. [58]

Moreover, empowerment techniques that are reinforced with emotional support for subordinates and create a supportive atmosphere can be more effective in strengthening self-efficacy beliefs and the positive psychological states of individuals [20]; [62]; [72]. Thus, it is expected that the individuals who are psychologically empowered will have higher level of psychological well being perception on condition that they perceive their supervisors social support in the workplace.

\section{CONCEPTUAL FRAMEWORK}

To summarize, previous research has found links between (a) psychological empowerment and selfefficacy, and (b) psychological empowerment and psychological well-being. However, to our knowledge there have not been studies that have investigated whether this relationship is mediated through self-efficacy and moderated by perception of supervisory social support.
With that respect, in order to understand how psychological empowerment relates to individual wellbeing it is important to understand the psychological mechanisms that may explain this relationship. It may be that psychological empowerment is primarily related to the individual's evaluation of his/her own competencies and ability to cope with challenges in the workplace which in turn then is associated with individual levels of well-being, however, it may also be that psychological empowerment is also related to how employees' perceive their supervisory social support. Thus, the perception of social support should be understood while questioning and explaining why individuals have a particular psychological state under a variety of contingents. From this perspective, it was supposed that the examination of the moderating role of supervisory social support would provide answers in part to the question of "why do the individuals (teachers) may not always have psychological well-being state at work in some circumstances although they have the perceptions of psychological empowerment in the workplace?".

Accordingly, we have developed the hypothesized relationships of the study involving psychological empowerment and psychological well-being perception with the mediating role of self-efficacy and intended to examine the moderating effect of social support between psychological empowerment and psychological wellbeing.

With that respect, it is expected that a strong sense of social support might contribute to a positive interpersonal state and greater satisfaction and therefore be related to higher levels of well-being in the individuals. This may be of particular importance in educational settings where social interactions and social support are perceived to be of particular importance e.g. [73]; [74]; [75]; [76]; [77]. It therefore still remains to be examined how psychological empowerment perception may be related to psychological well-being with the interference of individuals' cognitive appraisal of self-efficacy and the conditional affect of supervisory social support. To sum up, this study aims to build on previous research by testing the following three hypotheses:

Hypothesis1. Psychological empowerment will correlate positively with psychological well being.

Hypothesis2. The relationship between psychological empowerment and psychological well being is mediated by individuals' self-efficacy perception.

Hypothesis3. The relationship between psychological empowerment and psychological well being is moderated by individuals' social support perception.

The conceptual/theoretical framework of the relationships between psychological empowerment, selfefficacy, social support and psychological well-being are summarized in Figure 1. 


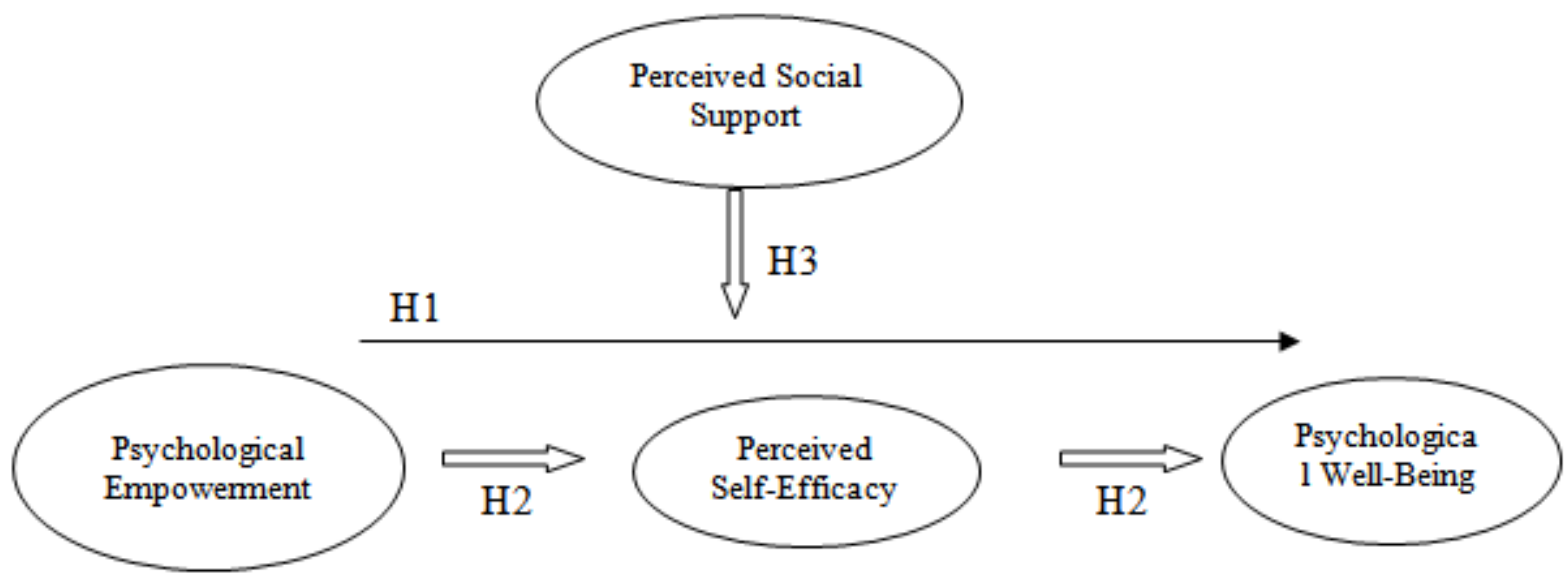

Figure 1. The Hypothesized Model

\section{THE METHOD}

The purpose of this study was to investigate perceptions of teachers' psychological empowerment, self-efficacy, social support and well-being in public primary schools in Kadıköy county of Istanbul. While a number of research studies pointed to increased achievement for teachers who were empowered in their particular work environment, a great number of questions remain regarding where school systems need to focus their effort to improve working conditions and productivity among teachers e.g. [73]; [78]; [79]; [80]. The purpose of this study was to determine the perceptions of teachers with their own reports. The independent variable was linked to Spreitzer's [14] conceptualization and operationalization of psychological empowerment and the dependent, mediating and moderating variables were linked to the self-orientations of the teachers. Thereby, the method part of the current study includes the research design and procedures, the participants, the instrumentation, the data analysis, and a summary of the findings.

\section{IV.1. Design and Procedure}

The study used a cross-sectional questionnaire survey design. The participants were asked questions about their perceptions of psychological empowerment, self-efficacy, social support and well-being and asked to rate their perceptions related to their workplace context on a variety of behaviors, situations and attributions.

Supervisory social support has been shown to operate, and be important, at the supervisory (managerial) level [76]; [81]. Thus, it is asked with a variety of supervisory social support behaviors. As further, teachers were surveyed on the four dimensions of self-orientation of meaning, competence, self-determination, and impact [14]; [82]. Questionnaire research in Turkey does not require approval by ethic committees and thus approval was not sought. However, the study was approved by the School Administration (school manager) and followed the regulations for confidentiality, data storage and protection. Also, before completing the questionnaire, participants (teachers) received information about the study and it was made clear that participation was voluntary. Also, participants returned their completed questionnaires directly to the researcher.

\section{IV.2. Participants}

The population for the study was six public primary schools in Kadıköy-Istanbul. County school systems were chosen for this study to gain a better perspective of teacher empowerment and well-being perceptions throughout the region. A random sample was selected from the population. Although many different size schools were investigated, the survey was performed in the schools with 350-600 students. For each school system, 30 participants were chosen. 10 teachers were selected from grades 1-5 and 20 were selected from grades 6-8 to ensure representative sample of $1^{\text {st }}-8^{\text {th }}$ grade teachers. The teachers were randomly sampled using the school administration's information in each school system. Permission was obtained from the manager (director) of schools to have access to the teachers who were selected to be a part of the study. The researcher also made contact with each school system's guidance and psychological counselor department to ensure their school system could accept the survey in the form of a questionnaire. The guidance \& psychological counselor department helped the researcher by distributing the questionnaires to the teachers from each grades and by giving the full questionnaires of the teachers to the researcher.

The questionnaires were distributed to 180 teachers and 170 returned the questionnaire, yielding a response rate of $95 \% .91 \%$ were female, the average age was 41 ( $\mathrm{SD}=10.93)$, and they had been working in their current workplace for 7 years on average. About 120 teachers with 11-25 years of total work experience responded to the survey with the next highest number belonging to teachers with $0-10$ years of experience (41 respondents). The remaining 9 teachers responded that 
they had more than 26 years of experience. Additionally, the teachers responded that they served children in rural populations $(40.9 \%)$. A minority of teachers held a master's degree $(1.5 \%)$. The two percentages of respondents came from grades $1-5(46 \%)$ and grades $6-8$ (54\%).

\section{IV.3. Measures}

Psychological empowerment. The instrument for data collection of psychological empowerment was the PEI developed by Spreitzer [14] and the items were adapted to the school context by adding a few school term. The instrument was designed to collect quantitative data about teacher psychological empowerment. The examples for the items are "My job activities I do are personally meaningful to me" (Yapmakta olduğum işimi anlamlı buluyorum), "I have a great deal of control over what happens in my school" (Okulumdaki olaylar üzerindeki kontrolüm oldukça fazladır). There was a sixpoint Likert scale associated with the instrument. The points of the scale were Very Strongly Agree, Strongly Agree, Agree, Neutrally Agree, Disagree, and Very Strongly Disagree. Numerical codes were attached to the varying degrees of the scale for statistical analysis. The researcher chose this instrument because it could effectively answer the research question as the research questions focused on four dimensions of psychological empowerment. The dimensions were Meaning, Competence, Self-determination, and Impact. Three questions were formulated for each dimension totaling 12 questions for the instrument. The instrument has been proven to be highly valid and reliable [14]; [15].

Self-efficacy. Initially, the researcher referred to a reduced seven-item version of self-efficacy [83]; [84]. The original scale items were rated on a 6-point scale ranging from - totally disagree to - totally agree. The Turkish adaptation of the scale was made by [85]. However, the researcher made minor changes on this Turkish translation before including this scale in the final questionnaire.

The researcher has revised the items in order to ensure content validity and the translated versions were given to 5 participants; all of whom were eligible for the analysis of the items. 3 of the review participants were academic lecturers; associate professors and doctor lecturer working in Marmara University Department of Organizational Behavior and Management-Organization; as 2 of the participants were doctorate degree students in PhD class of Management-Organization Department. The wording of some items was changed according to specific input received. [30] No reverse items were used in that measure and in that study, the internal consistency of this scale was found to be .904 [30]. Thus, in the current study, it is decided to use 6-point Likert scale from -definitely not appropriate, - definitely appropriate for each of the 10 items. (Refer to Bal Taştan [30] for the final version of the 10 items Self-Efficacy Perception scale used in the current questionnaire survey) An example of an item is "I can always manage to solve difficult problems if I try hard enough" (Ĕger gayret edersem güç sorunların çözümünü her zaman bulurum).

Psychological well-being. Warr [39]; [86] hypothesized a multidimensional model of work-related psychological well-being in which well-being is represented by two orthogonal dimensions (pleasure and arousal) but is measured by three dimensions: pleasure, anxiety-contentment and depression-enthusiasm. Warr [86] proposed two scales to measure these last two dimensions, as he suggested that the dimension of pleasure had already been successfully measured in the literature by the construct of job satisfaction. According to this suggestion, in this study, work related psychological well-being was measured by a 12-item scale as developed by Warr [86] and also used and confirmed by Atilla Bal [40]. The scale items were rated on a 6-point scale ranging from "never" to "always". The Turkish translation of the scale was done by the researcher. The psychological well-being items were asked with the paraphrase explanation of "Thinking of the past few weeks, how much of the time has your job made you feel each of the following". As suggested by Warr [86], axis two regarding job-related anxiety-contentment, was assessed through the adjectives; tense, uneasy, worried, calm, contented and relaxed. Responses to the first three items were reverse-scored, so that high scores indicated positive psychological well-being. Similarly, axis three, regarding job-related depression-enthusiasm, was tapped by the adjectives; depressed, gloomy, miserable, cheerful, enthusiastic and optimistic. The first three items were again reverse-scored. The overall internal consistency of this scale was found to be .705.

Supervisory Social Support. Supervisor Support was measured by a six-item scale developed by Grandey [87] and a single item developed by Ünler-Öz [88]. The Turkish translation of the scale was done by Ünler-Öz [88]. These items were then back translated by to see how the two versions compared and were used after the necessary corrections were made. Thus, the scale was also used by Atilla Bal [40] and the items' content validity were ensured. In this current study, the scale consists of seven items, all of which were rated on a 6-point scale ranging from "totally disagree" to "totally agree". The higher points depict higher levels of supervisor support. Sample items from this measure are "My supervisor helps me through demanding times at work", "When things go wrong, I can let my supervisor know about it without being fearful", etc. In this study, the internal consistency of this scale was found to be .890 .

\section{IV.4. Analysis}

Based on the proposed model and the hypotheses, several statistics were performed for the reliability and factor analyses of the independent (psychological empowerment), mediating (self-efficacy) and dependent 
(psychological well-being) variables. The reliabilities of the constructs in each scale were determined by Cronbach's Alpha and the correlations among all study variables were calculated by Pearson's Correlation. Regression analyses were performed for testing the relationships between the independent variable (psychological empowerment) and the mediating variable (self-efficacy); the mediating variable (self-efficacy) and the dependent variable (psychological well-being); and for testing the mediating variable (self-efficacy) between the independent (psychological empowerment) and dependent (psychological well-being)variables.

Moreover, in this study, within the conceptual framework, the perception of supervisory social support was viewed as a moderating (contingent) variable as it was suggested that perceiving the social support presented by the superiors would be important in individuals' perception of psychological well-being at work. Thus, the perception of social support is measured as a moderating variable by carrying out hierarchical regression analysis (moderated multiple regression analysis) in order to test the moderating effect of social support on the relationship of psychological empowerment and psychological wellbeing at work.

\section{FINDINGS}

V.1. Factor and Reliability Analyses for the Scales of Psychological Empowerment and Psychological Well-Being

\section{V.1.1. Factor Analysis for Psychological Empowerment Scale}

The scales that are used in this study were simplified as the result of factor analysis done during the pilot study. The factor analysis is done for all the scales used in this study. Principal Components analysis is primarily used followed by confirmatory Principal Axis Factoring analysis. In both analyses, orthogonal Varimax rotation is used, whilst only factors with eigenvalue greater than 1 are taken into consideration. The items are eliminated according to the priorities that were already set at the previous stage of the study. In other words, the items which have factor loadings less than .50 are eliminated in first place, then items with equal factor loadings or weights; thirdly items which are left single or one item equals one factor are considered to be deleted. The sampling adequacy is tested by Kaiser- Meyer Olkin (KMO) coefficient which is expected to exceed ,60; and by Bartlett's test of sphericity to be meaningful.

Table 1. Factor Analyses Results of Psychological Empowerment Scale

\begin{tabular}{|c|c|c|c|}
\hline Item No & Psychological Empowerment Factors & \%Variance Explained & Cronbach $\alpha$ \\
\hline & Factor I: Meaning & 28,209 & ,94 \\
\hline 1 & $\begin{array}{l}\text { Yaptığım iş benim için çok önemlidir. } \\
\text { My job seems very important to me. }\end{array}$ & & \\
\hline 2 & $\begin{array}{l}\text { İşimle ilgili yaptığım faaliyetler benim için özel bir anlam taşır. } \\
\text { The activities I do in my job are having special meaning for me. }\end{array}$ & & \\
\hline \multirow[t]{2}{*}{3} & $\begin{array}{l}\text { Yapmakta olduğum işi anlamlı buluyorum. } \\
\text { My job activities I do are personally meaningful to me. }\end{array}$ & & \\
\hline & Factor 2: Self-Determination & 24,206 & ,92 \\
\hline 7 & $\begin{array}{l}\text { İşimi nasıl yürüteceğime dair kararları kendim verebiliyorum. } \\
\text { I can give the decisions about how I will do my job. }\end{array}$ & & \\
\hline 9 & $\begin{array}{l}\text { İşimi yaparken farklı yöntemleri seçme konusunda özgürüm. } \\
\text { I feel free to choose different methods while doing my job. }\end{array}$ & & \\
\hline \multirow[t]{2}{*}{11} & $\begin{array}{l}\text { Okulumdaki olaylar üzerindeki kontrolüm oldukça fazladır. } \\
\text { I have a great deal of control over what happens in my school. }\end{array}$ & & \\
\hline & Factor 3: Competency & 22,550 & ,89 \\
\hline 5 & $\begin{array}{l}\text { İşimi yapmak için gereken kapasiteye sahibim. } \\
\text { I have the required capacity for doing my job. }\end{array}$ & & \\
\hline 4 & $\begin{array}{l}\text { İşimi yapmak için gereken yeteneklere sahip olduğuma eminim. } \\
\text { I am confident that I have the required abilities for doing my job. }\end{array}$ & & \\
\hline \multirow[t]{2}{*}{6} & $\begin{array}{l}\text { İşim için gereken becerilere uzmanlık seviyesinde sahibim. } \\
\text { I have the required skills with specialty for my job. }\end{array}$ & & \\
\hline & Factor 4: Impact & 15,056 &, 88 \\
\hline 10 & $\begin{array}{l}\text { Okulumdaki gelişmeler üzerindeki etkim oldukça fazladır. } \\
\text { I have a great deal of effect over the developments in my school. }\end{array}$ & & \\
\hline \multirow[t]{2}{*}{12} & $\begin{array}{c}\text { Okulumdaki olaylar üzerindeki nüfuzum oldukça fazladır. } \\
\text { I have a great deal of influence over what happens in my school. }\end{array}$ & & \\
\hline & $\begin{array}{c}\text { KMO=0,9112 } \\
\text { Chi-Square Bartlett's Test }=1514,524 \\
P=0,000\end{array}$ & 80,021 & ,91 \\
\hline
\end{tabular}


Consistent with Spreitzer's [14]; [15] methodology, factor analyses using a principle components solution with Varimax rotation was applied to the 12 items representing the dimensions of psychological empowerment to determine whether the four factors found by Spreitzer would emerge again. Numerous rotations were made to obtain the best representation of the data and one item was left out of the analysis that did not have large factor loadings $(<0.40)$. It is seen that four of the psychological empowerment dimensions were found as a result of the factor analysis which are consistent with Spreitzer's dimensions meaning, impact, self-determination and competency. However, the eleventh item (Okulumdaki olaylar üzerindeki kontrolüm oldukça fazladır/I have a great deal of control over what happens in my school), which is included to the "impact" dimension in the original scale, occurred under "self-determinism" dimension in this research study.

The four factors yielded a KMO value of .890 and the Bartlett's test of sphericity yielded a significant result with a $\mathrm{p}=.000$. Therefore, it was concluded that the data is appropriate for carrying out the factor analysis and that the factor analysis results are valid. The 11 items loaded under four factors which explained $80.021 \%$ of the total variance. The Cronbach Alpha values were determined as .91 for the total variable. The detailed report of the Psychological Empowerment Scale factor analysis is shown in Table1.

\section{V.1.2. Factor Analysis for Psychological Well-Being Scale}

Psychological Well-Being scale was factor analyzed using Varimax rotation. Numerous rotations were made to obtain the best representation of the data and two items were left out of the analysis that did not have large factor loadings $(<0.40)$ and that had crossloadings. The results of the factor analyses indicate that the psychological well-being scale consisted of two factors and these new factors were named as "negative affections" and "positive affections"-. The 10 items loaded under two factors which explained $76.350 \%$ of the total variance. The two factors yielded a KMO value of .850 and the Bartlett's test of sphericity yielded a significant result with a $\mathrm{p}=.000$. Therefore, it was concluded that the data is appropriate for carrying out the factor analysis and that the factor analysis results are valid. The Cronbach Alpha values were determined as .91 for negative and .89 for positive affections respectively. The detailed report of the Work-related Psychological Well-being Scale factor analysis is shown in Table 2.

Table 2. Factor Analysis Results of Psychological Well-Being Scale

\begin{tabular}{|c|c|c|c|}
\hline Psychological Well-Being Factors & \%Variance Explained & Factor Loading & Cronbach $\alpha$ \\
\hline Factor I: Negative Affections & 40,865 & & 91 \\
\hline Gloomy & & ,895 & \\
\hline Uneasy & & ,868 & \\
\hline Worried & & 862 & \\
\hline Depressed & &, 851 & \\
\hline Miserable & & ,797 & \\
\hline Tense & & ,688 & \\
\hline Factor 2: Positive Affections & 35,485 & & ,89 \\
\hline Optimistic & & ,855 & \\
\hline Enthusiastic & & ,842 & \\
\hline Cheerful & & 828 & \\
\hline Contented & & , 7920 & \\
\hline $\begin{array}{c}\text { KMO=0,9112 } \\
\text { Chi-Square Bartlett's Test }=\mathbf{1 5 1 4 , 5 2 4} \\
P=0,000\end{array}$ & 80,021 & & ,91 \\
\hline
\end{tabular}

\section{V.2. Correlation Analysis between the Variables}

According to the preliminary statistical analysis, the scales, means, standard deviations, scale reliabilities, and intercorrelations of all variables in the study are evaluated. Further, skewness and kurtosis were all below 1.93 indicating normal distribution of the data. The measures relevant to our mediation models were significantly correlated, i.e. measures of psychological empowerment, the hypothesized mediating self-efficacy variable and psychological well-being. Subsequently, in the study, the conditions for further analysis of the mediation model were satisfied.It was seen that all of the variables of the research model showed significant correlations between each other (Correlation is significant at the 0.05 level/2-tailed). Especially, the independent variable (psychological empowerment) has shown positive significant correlations with dependent variable (psychological well-being). The self-efficacy perception variable also has showed positive significant correlation with psychological well-being.

By examining the findings, in order to interpret correlation between the independent variable (psychological empowerment), mediating variable (selfefficacy), dependent variable (psychological well-being), 
and moderating variable (social support), it can be implied that the results indicate:

- a strong positive correlation $(\mathrm{r}=0,787)$ between psychological empowerment and psychological wellbeing $(\mathrm{p}<0,05)$

- a moderate positive correlation $(r=0,682)$ between self-efficacy perception and psychological well-being $(\mathrm{p}<0,05)$

- a moderate positive correlation $(r=0,511)$ between supervisory social support and psychological wellbeing $(\mathrm{p}<0,05)$

In sum, it is interesting to note that the quite high and meaningful correlation between psychological empowerment and psychological well-being ( $\mathrm{r}=, 78$; $\mathrm{p}<.05)$. The relation, measured by analyzing the $r$ values, between the independent and dependent variable of the research model is significant and high. The correlation between the self-efficacy -which is the mediating variable of the research- and psychological well-being is moderate positive, thus there is moderate and significant relation with the self-efficacy and psychological well-being $(\mathrm{r}=$ $, 68 ; \mathrm{p}<.05)$.

\section{V.3. Testing the Hypotheses}

The analysis started with a set of linear (single) regression analysis applied between the dependent and independent variable of the model. Then, the interactive impact of various variables in the research model were tested by including all research variables in regression analysis applied by using the multiple and hierarchical (stepwise) regression technique.

\section{V.3.1. Results of Single Regression Analysis}

The single regression analysis was done taking the psychological empowerment dimensions as the independent variables, and the psychological well-being as the dependent variable. The results are shown below.

From the Table 3 and Table 4, it can be seen that $\mathrm{R}$ Square is $0,714, \mathrm{~F}$ is 36,788 and Significance level is 0,000 , thus, it can be stated that according to the regression results, the independent variables jointly explained $79,4 \%$ of the variance in the dependent variable, psychological well-being. ( $\mathrm{F}=36,788, \mathrm{p}<0,05)$.

Table 3. Model Summary of Regression Analysis

\begin{tabular}{c|c|c|c|c}
\hline Model & R & R Square & Adjusted R Square & Std. Error of the Estimate \\
\hline 1 &, $872(\mathrm{a})$ &, 794 &, 611 &, 47263 \\
\hline \multicolumn{7}{|c}{ Predictors: (Constant), Meaning, Impact, Self-Determination, Competency } \\
\hline
\end{tabular}

Table 4. Regression Analysis of Psychological Empowerment Dimensions and Psychological Well-Being

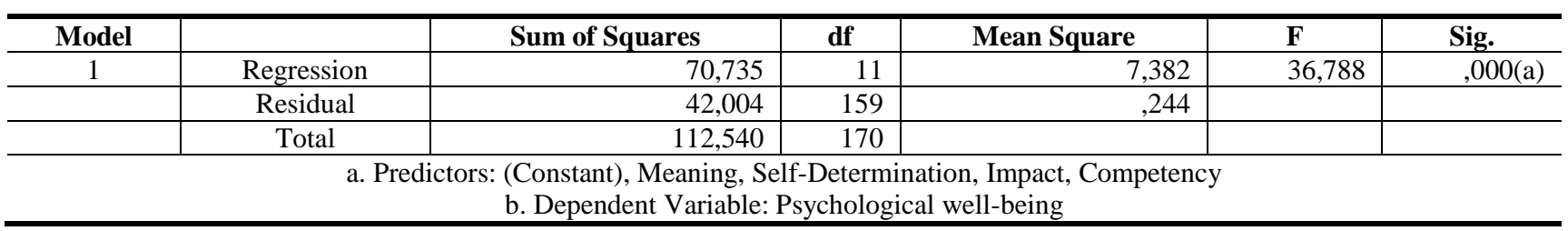

Table 5. Coefficients of Regression Analysis

\begin{tabular}{|c|c|c|c|}
\hline \multicolumn{2}{|c|}{ Dependent Variable: Psychological Well-Being } & \multirow[b]{2}{*}{ t Value } & \multirow[b]{2}{*}{ P Value } \\
\hline Independent Variables & Beta & & \\
\hline Constant & & $-0,085$ & 0,928 \\
\hline Meaning & 0,488 & 3,828 & 0,000 \\
\hline Self-Determination & 0,395 & 2,225 & 0,004 \\
\hline Impact & 0,269 & 2,988 & 0,028 \\
\hline Competency & 0,225 & 2,556 & 0,022 \\
\hline \multicolumn{3}{|c|}{$\mathrm{R}=\mathbf{0 , 8 7 2} ; \mathrm{R}^{2}=\mathbf{0 , 7 9 4} ; \mathrm{F}$ Value=36,788; $\mathrm{P}$ Value=0,000 } & \\
\hline
\end{tabular}

Consequently, it can be suggested that all four psychological empowerment dimensions are meaningfully and positively related to the psychological well-being. When the statistical results of the analysis are examined, it is seen that the "meaning" dimension of psychological empowerment explains $48.8 \%$ of the perception of psychological well-being, "self-determination" explains $39.5 \%$, "impact" explains 26.9\%, and "competency" explains $22.5 \%$ of psychological well-being. Therefore, "Hypothesis 1" is "confirmed". As further, in this study, $\mathrm{R} 2=0,794$ and it can be implicated that perceived psychological well-being of the individuals (teachers) who have been participated in the survey is effected by psychological empowerment by $79 \%$. The rest $21 \%$ can be explained with the influence of factors other than psychological empowerment. 


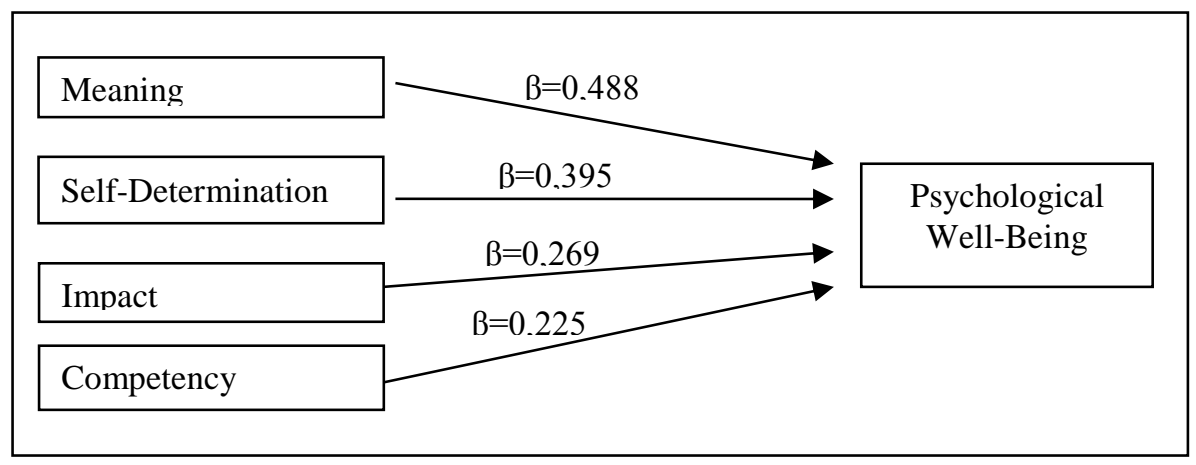

Figure 2. Research Model of the Relationship between Psychological Empowerment Dimensions and Psychological Well-Being after Regression Analysis

\section{V.3.2. Test of the Mediating Role of Empowerment}

In the next stage, a full mediation model (Hypothesis 2) was tested. In this model a link from psychological empowerment to self-efficacy and from self-efficacy to psychological well-being was included. In this model, psychological empowerment with all dimensions is taken as the independent; the psychological well-being as the dependent and the self-efficacy perception is takes as the mediating variable. For testing the mediating role of self-efficacy, a three step analysis is performed [89]:

- In the first step, multiple regression between the independent variable and the mediator,

- In the second step, multiple regression between the independent variable and the dependent variable,
- In the third step, a multiple regression with the independent variable and the dependent variable with the inclusion of the mediator is performed.

In order to confirm the mediating role of a variable, the regression analysis in the first two steps should give meaningful results, the mediating variable should also be related to the dependent variable significantly, and the beta coefficient of the mediating variable in explaining the dependent variable should be higher than the independent variable's beta values in order to consider a partial mediation. A full mediation would require the complete reduction of independent variable's effect on the dependent variable after the inclusion of the mediating variable. Accordingly, the results of the analysis are displayed on Table 6.

Table 6. The Mediating Role of Self-Efficacy between Psychological Empowerment and Psychological Well-Being

\begin{tabular}{|c|c|c|c|c|c|}
\hline VARIABLES & $\boldsymbol{B}$ & $\beta$ & $R^{2}$ & $\operatorname{Adj.} R^{2}$ & $\boldsymbol{F}$ \\
\hline $\begin{array}{l}\text { 1.STEP (1) } \\
\text { Psychological Empowerment }\end{array}$ & ,326 &, $376 *$ &, $677 * * *$ & ,623 & 36,755 \\
\hline $\begin{array}{l}2 . \text { STEP (2) } \\
\text { Psychological Empowerment }\end{array}$ &, $281 *$ &, $295 *$ &, $227 * * *$ & ,215 & 22,533 \\
\hline $\begin{array}{l}\text { 3.STEP (3) } \\
\text {-Psychological Empowerment } \\
\text {-Self-Efficacy }\end{array}$ & $\begin{array}{l}, 498^{*} \\
, 329^{*}\end{array}$ & $\begin{array}{l}, 544^{*} \\
, 418^{*}\end{array}$ &, $686 * * *$ & ,623 & 55,722 \\
\hline
\end{tabular}

$* \mathrm{p}<.05 * * \mathrm{p}<.01 * * * \mathrm{p}<.001$

(1) 1. Step: Dependent variable: Self-Efficacy Perception; Independent variable: Psychological Empowerment

(2) 2. Step: Dependent variable: Psychological Well-Being; Independent variable: Psychological Empowerment

(3) 3. Step: Dependent variable: Psychological Well-Being; Independent variables: Psychological Empowerment and Self-Efficacy Perception

According to the results of Table 6, it is seen that the mediating role of self-efficacy could be confirmed as in Step 3 of the analysis; the beta coefficient of psychological empowerment is stronger than Step 2. Thus, the results meaningfully support the mediating contribution of self-efficacy perception between psychological empowerment and psychological wellbeing.

As it was told about the examination conditions of the mediating variable previously, the case of inclusion of self-efficacy as a mediating variable showed that the effect of independent variable on dependent variable is lower when the mediating variable is not included.
At this point, the results indicated that there is a significant and positive relationship between psychological empowerment perception and self-efficacy perception $(\beta=0.326, p<0.05)$. In the final step of the model, with the inclusion of self-efficacy in the analysis, the effect of the psychological empowerment on psychological well-being has increased $(\beta=0.544, \mathrm{p}<0.05)$. It was seen that in the third step the beta coefficient was higher than the second step $(\beta=0.295, \mathrm{p}<0.05)$.

This result reveals that as a lone the psychological empowerment perception has a lower effect on well-being than with the mediating effect of the self-efficacy perception. Consistent to what was expected, with the 
inclusion of the self-efficacy, the effects of psychological empowerment on well-being increased and self-efficacy was significant. It can be suggested that the explanatory power of psychological empowerment perception and self-efficacy together on psychological well-being is confirmed and there is a partial mediation role of selfefficacy in the research model.

Therefore, it can be concluded that self-efficacy is a mediator between psychological empowerment perception and psychological well-being. As the reports confirms the mediating role of self-efficacy is confirmed and "Hypothesis 2" is "supported".

\section{V.3.3. Test of the Moderating Role of Supervisory Social Support}

In this study, theoretically, it was assumed that the degree to which individuals perceive the social support from their supervisors can change their situation of feeling work related psychological well-being. Therefore, within the framework of the research model, it is expected to observe that contingent effects of "perception of social support" would have a moderating role on the relationship between individuals' (teachers) perceptions of psychological empowerment and their psychological well-being state.
As it was stated by Sharma [90], the moderator variable changes the intensity, rather than the direction of a relation. In order to test the Hypothesis 3, which sets the moderating role of social support perception, a moderated multiple regression analysis (hierarchical regression analysis) was applied as shown on Table 7. In the first step, the psychological empowerment was entered; in the second step the psychological well-being was entered and in the third step the interactions or combined effect between all the variables that have entered into the regression equation, are introduced. All variables have been standardized before starting the test.

The results of hierarchical regression analysis showed that perception of social support has moderating impacts on the relationship between psychological empowerment and psychological well-being. Therefore, according to the moderated regression analysis results, "Hypothesis 3" which has suggested that perception of social support would moderate the relationship between perceived psychological empowerment and psychological well-being "was supported". That means the suggestion of the higher the perception of social support, the stronger the relationship between perceived psychological empowerment and psychological well-being was confirmed.

Table 7. The Moderating Role of Social Support Perception between Psychological Empowerment and Psychological Well-Being

\begin{tabular}{|c|c|c|c|c|}
\hline Independent Variable & Standard Beta & Sig. & $\operatorname{Adj.R^{2}}$ & Model F Value \\
\hline $\begin{array}{l}\text { Step } 1 . \\
\text { Psychological Empowerment }\end{array}$ & ,585 &, 000 & ,322 & $152,651 *$ \\
\hline $\begin{array}{l}\text { Step } 2 . \\
\text { Psychological Empowerment } \\
\text { Social Support }\end{array}$ & $\begin{array}{l}, 552 \\
, 212\end{array}$ & $\begin{array}{l}, 000 \\
, 000\end{array}$ &, 353 & $90,725^{*}$ \\
\hline $\begin{array}{l}\text { Step } 3 . \\
\text { Psychological Empowerment x Social Support }\end{array}$ &, 000 & 1,000 &, 367 & $60,100 *$ \\
\hline
\end{tabular}

Dependent Variable: Psychological Well-Being $*_{p}<, 001$

Consequently, the results of the Table 7 reveal that the perception of social support has been proved as a moderator between psychological empowerment perception and psychological well-being. $(\mathrm{B}=, 000 ; \mathrm{p}=$ 1,000; significant) and the third step shows that the adjusted square for the interaction term was higher than the second step (Step2: Adj. $\mathbf{R}^{2}=, 353 ;$ Step3: Adj. $\mathrm{R}^{2}=$ ,367). That means the interaction of supervisory social support increased the explanatory on the psychological well-being as a moderator variable.

\section{CONCLUSION AND DISCUSSION}

This study analyzed the relationship between psychological empowerment and psychological wellbeing at work and examined the mediating effect of selfefficacy on the relevant relationship. As further, the study aimed to examine the moderating role supervisory social support on the relationship between psychological empowerment and psychological well-being.
According to the relevant literature, psychological empowerment plays a critical role in individuals' attitudes, behaviors, and psychological outcomes such as well-being at work. Since psychological empowerment is said to be an antecedent of a more humanized and moralized workplace, it was worthwhile to examine the relationship between psychological empowerment and work related psychological well-being.

According to the findings of this study, it was seen that psychological empowerment had a big contribution on the outcome of psychological well being and this finding supported the related studies' results which have revealed that well-being was an important outcome of psychological empowerment -e.g. [31]; [32].

As further, the results of this study indicated that all the psychological empowerment dimensions had an effect on psychological well-being. It is seen that the "meaning" and "self-determination" dimensions of psychological empowerment were the ones having the 
most explanatory power on the perception of psychological well-being. The feeling of meaningfulness about the work and having a perception of autonomy or self-determination over the work have been concerned with individuals' satisfaction and intrinsic motivation, individualized and holistic interests towards the their work and related to their positive psychological states e.g. [19]; [13]; [14]; [37]. Additionally, the results of this study was consistent with Deci and Ryan's [44] study which have implied that individuals' perceptions of competence are related with higher psychological wellbeing, motivation, and performance in the workplace. Therefore, it can be suggested that the results of this study are supported by the literature.

Furthermore, in this study it is confirmed that the self-efficacy perception significantly mediates the relationship between psychological empowerment and psychological well-being perception of the individuals (teachers). As a result, it was seen that psychological empowerment has an antecedent role for self-efficacy perception and self-efficacy increases the explanatory power of psychological empowerment on psychological well-being. Thus, being consistent with the literature [47]; [48]; [49], those with high self-efficacy are more likely to cope with stressful situations at work and feel higher positive psychological states than those with low selfefficacy. It is seen that the results of this study are also consistent with the Self-Efficacy Theory's [55] and Social Cognitive Theory's [19] implications and also O'Leary's [50] study which has indicated that self- efficacy beliefs play a major role in positive psychological and physical health outcomes.

Another finding of the study is that supervisory social support had a significant moderating role on the relationship between psychological empowerment and psychological well-being. This can be explained by the perception of the individuals about their gained social support from their supervisors in an organization which increases their well-being state. Since psychological wellbeing is a consequence of a psychological process of being psychologically empowered and cognitive evaluations about their work; it is meaningful that a perception of social support which is includes a variety of behaviors by which a manager shows consideration, acceptance and concern for the needs and feelings of individuals would increase the affect of psychological empowerment on psychological well-being. Accordingly, it is recognized that the results of this study support the outcomes and suggestions of the previous works [13]; [14]; [24]; [91].

With that respect, it is suggested that the results of this study are consistent with the implications of SelfDetermination Theory [62] which indicated that work contexts supporting psychological autonomy and enhancing social support increase intrinsic motivation and psychological outcomes of the individuals [63]. As further, this study's result is consistent with Spreitzer's
[15] study which has addressed that individuals who perceive that they have high levels of socio-political support from their immediate supervisor have higher levels of empowerment and higher levels of positive attitudes and feeling at work.

However, some limitations should be considered when interpreting the results of this study. First, the study draws from the psychological empowerment paradigm. The Psychological Empowerment Scale used in this study is a useful and reliable instrument, but might not be an exhaustive account of psychological empowerment perception within various survey contexts. It is supposed that although this study used a broad, reliable and valid measure of psychological empowerment to test the validity of mediated relationships, more original measurement instrument could be used in order to gain "emic" (qualitative method) evaluations about empowerment in the form of psychological state. Even so, the measures chosen were well-suited to a study population in this study: it was considered that a lengthy questionnaire would adversely influence response rates without leading to substantial gains in reliability and validity. In future research it would be interesting to examine the role of other dimensions of empowerment, for example to identify whether contextual empowerment exhibit direct effects on self-efficacy and well-being.

Second, the data presented is cross-sectional, and subsequently we are unable to comment on causality. Drawing on longitudinal designs and individualsupervisor dyads may help to further our understanding of the direction the relationships between psychological empowerment, self-efficacy beliefs, social support and the individual well-being, and provide further validation of these complex relationships.

A third limitation of this study is that the research survey has been done in public primary schools in Istanbul-Kadıköy, Turkey. The advantages of this research were the control over the organizational and managerial characteristics and the collection of data from several primary schools scattered across Istanbul. However, using only public entities might have caused limitations on the validity of the survey.

\section{REFERENCES}

[1] Sofarelli, D. \& Brown, D. (1998). The need for nursing leadership in uncertain times. Journal of Nursing Management, 6, 201-207.

[2] Thyer, G. (2003). Dare to be different: transformational leadership may hold the key to reducing nursing shortage. Journal of Nursing Management, 11, 73-79.

[3] Medley, F. \&Larochelle, D. (1995). Transformational leadership and job satisfaction. Nursing Management, 26, 640-659.

[4] Nielsen, K., Randall, R., Yarker, J. \& Brenner, S.O. (2008). The effects of transformational leadership on followers' perceived work characteristics and psychological wellbeing: A longitudinal study. Work \&Stress, 22 (1), 16-32. 
[5] Nielsen, K., Yarker, J., Brenner, S., Randall, R. \& Borg, V. (2008). The importance of transformational leadership style for the well-being of employees working with older people. Journal of Advanced Nursing, 63 (5), 465-475.

[6] Herrenkohl, R.C., Judson, G.T. \& Heffner, J.A. (1999). Defining and measuring employee empowerment. Journal of Applied Behavioural Science, 35(3), 373-389.

[7] Block, P. (1993). Stewardship. Berrett-Koehler, San Francisco.

[8] Walton, R.E. (1985). From control to commitment in the workplace. Harvard Business Review, 63(2), 77-84.

[9] Senge, P. (1990). The fifth discipline: the art and practice of the learning organization. Doubleday/Currency, New York.

[10] Tracey, D. (1990). 10 Steps to Empowerment: A Common Sense Guide to Managing People. William Morrow, New York.

[11] Dee, J.R., Henkin, A.B. \& Duemer, L. (2003). Structural antecedents and psychological correlates of teacher empowerment. Journal of Educational Administration, 41(3), 257-277.

[12] Potterfield, T. A. (1999). The business of employee empowerment: Democracy and ideology in the workplace. Westport, CT: Quorum Books.

[13] Conger, J. A., Kanungo, R. N. (1988). The empowerment process: Integrating theory and practice. Academy of Management Review, 13, 471-482.

[14] Spreitzer, G. M. (1995). Psychological empowerment in the workplace: Dimensions, measurement, and validation. Academy of Management Journal, 38(5), 1442-1465.

[15] Spreitzer, G. M. (1996) Social structural characteristics of psychological empowerment. Academy of Management Journal, 39(2), 483-504.

[16] Spreitzer, G. M., Kizilos, M. A. \& Nason, S. W. (1997). A dimensional analysis of the relationship between psychological empowerment and effectiveness, satisfaction, and strain. Journal of Management, 23(5), 679-704.

[17] Thomas, K. W., Velthouse, B. A. (1990). Cognitive elements of empowerment: An interpretive model of intrinsic motivation. Academy of Management Review, 15 , 666-681.

[18] Bordin, C., Bartram, T. \& Casimir, G. (2007). The antecedents and consequences of psychological empowerment among Singaporean IT employees. Management Research News, 30(1), 34-46.

[19] Bandura, A. (1986). Social foundations of thought and action: A social cognitive view. Englewood Cliffs, Prentice-Hall, New Jersey.

[20] Bandura, A. (1977). Self-efficacy: Toward a unifying theory of behavioral change. Psychological Review, 84 191-215

[21] Spreitzer, G. M., De Janasz, S. C. \& Quinn, R. E. (1999). Empowered to lead: The role of psychological empowerment in leadership. Journal of Organizational Behavior, 20, 511-526.
[22] Menon, S.T. (2001). Employee empowerment: An integrative psychological approach. Applied Psychology: An International Review, 50(1), 153-180.

[23] Meyerson, S.L. \& Kline, T.J.B. (2008). Psychological and environmental empowerment: Antecedents and consequences. Leadership \& Organization Development Journal, 29(5), 444-460.

[24] Liden, R.C., Wayne, S.J. \& Sparrowe, R.T. (2000). An examination of the mediating role of psychological empowerment on the relations between the job, interpersonal relationships and work outcomes. Journal of Applied Psychology, 85(3), 407-416.

[25] Avolio, B., Zhu, W., Koh, W. \& Bhatia, P. (2004). Transformational leadership and organizational commitment: mediating role of psychological empowerment role and moderating role of structural distance. Journal of Organizational Behavior, 25, 951-968.

[26] Seibert, S., Silver, S. \& Randolph,W. (2004). Taking empowerment to the next level: a multiplelevel model of empowerment, performance, and satisfaction. Academy of Management Journal, 47, 332-350.

[27] Kirkman, B.L. \& Rosen, B. (1999). Beyond selfmanagement: antecedents and consequences of team empowerment. Academy of Management Journal, 42(1), 56-74.

[28] Savery, L.K. \& Luks, A.J. (2001). The relationship between empowerment, job satisfaction and reported stress levels: some Australian evidence. Leadership \& Organization Development Journal, 22(3), 97-104.

[29] Koberg, C.S., Boss, R.W., Senjem, J.C. \& Goodman, E.A. (1999). Antecedents and outcomes of empowerment. Group \& Organization Management, 24(1), 71-92.

[30] Taştan, S.Bal.(2011). The mediating role of psychological empowerment on the relationship between participative organizational climate, self efficacy and individual performance behaviors. Unpublished Doctoral Thesis, Social Sciences Institute, Department of Organizational Behavior, Marmara University.

[31] McClain, A. (2001). Estimating the effects of empowerment on Black women's psychological well-being. Unpublished Doctoral Thesis, Graduate School of Social Work, Boston College.

[32] Tahira, J., Ruhi, K. \& Jibeen, R. K. (2010) Predictors of Psychological well-being of Pakistani Immigrants in Toronto, Canada. International Journal of Intercultural Relations, 34, 452-464.

[33] Diener, E., Lucas, R. E. \& Oishi, S. (2002). Subjective well-being: The science of happiness and life satisfaction. In C. R. Snyder \& E. S. J. The handbook of positive psychology (pp. 63-73). Oxford University Press, New York.

[34] Diener, E., Sapyta, J.J. \& Suh, E. (1998). Subjective wellbeing is essential to well-being. Psychological Inquiry, 9, 33-37.

[35] Seligman, M. E. P., \& Csikszentmihalyi, M. (2000). Positive psychology: an introduction. American Psychologist, 55, 5-14. 
[36] Eldeleklioğlu, J., Yılmaz, A. \& Gültekin, F. (2010). Investigation of teacher trainees' psychological tell-Being in terms of time management. World Conference on Educational Sciences, February 04-08, İstanbul. (Full text: Procedia-Social and Behavioral Sciences, 2 (2), 342-348).

[37] Ryan, R. M. \& Deci, E. L. (2001). Self-determination theory and the facilitation of intrinsic motivation, social development, and well-being. American Psychological Association, 55(1), 68-78.

[38] Ryff, C. D. (1989). Happiness is everything, or is it? Explorations on the meaning of psychological well-being. In G. J., Kafka, \& A. Kozma, (2002). The construct validity of Ryff's scales of psychological well-being (SPWB) and their relationship to measures of subjective well-being. Social Indicators Research, 57(2), 171.

[39] Warr, P. B. (1987). Work, unemployment, and mental health. Clarendon Press, . Oxford, England.

[40] Atilla Bal, E. (2008). Self-efficacy, contextual factors and well-being: The impact of work engagement. Unpublished Doctoral Thesis, Social Sciences Institute, Department of Organizational Behavior, Marmara University.

[41] Warr, P. B. (1994). A conceptual framework for the study of work and mental health. Work and Stress, 8(2), 84-97.

[42] Russell, J.A. \& Carroll, J.M. (1999). The phoenix of bipolarity: Reply to Watson and Tellegen. Psychological Bulletin, 125(5), 611-617.

[43] Keyes, L.M., Shmotkin, D. \& Ryff, C.D. (2002). Optimizing well-being: The empirical encounter of two traditions. Journal of Personality and Social Psychology, $82,1007-1022$.

[44] Deci, E. L. \& Ryan, R. M. (2000). The "what" and "why" of goal pursuits: Human needs and the self-determination of behavior. Psychological Inquiry, 11(4), 227-268.

[45] Fava, L. (2011). The relationship between complementary and alternative medicine use, psychological well-being. Unpublished Doctoral Thesis, The California School of Professional Psychology.

[46] Bandura, A. (1997). Self-efficacy: The exercise of control. Freeman, New York.

[47] Parker, L. (1994). Working together: Perceived self- and collective efficacy at the workplace. Journal of Applied Social Psychology, 24, 47-59.

[48] Jex, S.M., Bliese, P.D., Buzzell, S. \& Primeau, J. (2001). The impact of selfefficacy on stressor-strain relations: coping style as an exploratory mechanism. Journal of Applied Psychology, 86, 401-409.

[49] Nielsen, K., Yarker, J., Randall, R. \& Munir, F. (2009). The mediating effects of team and self-efficacy on the relationship between transformational leadership, and job satisfaction and psychological well-being in healthcare professionals: A cross-sectional questionnaire survey. International Journal of Nursing Studies, 46, 1236-1244.

[50] O'Leary, A. (1992). Self-efficacy and health: behavioral and stress-physiological mediation. Cognitive Therapy and Research, 16, 229-245.
[51] Jex, S.M. \& Dudanowski, D.M. (1992). Efficacy beliefs and work stress: an exploratory study. Journal of Organizational Behavior, 13, 262-279.

[52] Jex, S.M. \& Bliese, P.D. (1999). Efficacy beliefs as a moderator of the impact of work-related stressors: a multilevel study. Journal of Applied Psychology, 84, 349361 .

[53] Stetz, T.A., Stetz, M.C. \& Bliese, P.A. (2006). The importance of self-efficacy in the moderating effects of social support on stressor-strain relationships. Work \& Stress, 20, 49-59.

[54] Zellars, K.L., Hochwarter, W.A., Perrewe, P.L., Miles, A.K. \& Kiewitz, C. (2001). Beyond self-efficacy: interactive effects of role conflict and perceived collective efficacy. Journal of Managerial Issues, 13, 483-499.

[55] Bandura, A. (2000). Cultivate self-efficacy for personal and organizational effectiveness. In E. A. Locke (Ed.), The Blackwell handbook of principles of organizational behavior (pp.120-136), Blackwell, Oxford, UK.

[56] Lawler, E. E. (1986). High involvement management: Participative strategies for improving organizational performance. Jossey-Bass, San Francisco.

[57] Spencer, S.M. (2006). Effects of social support and heterosexism on the psychological well-being of diverse adults. Unpublished Doctoral Thesis, Eberly College of Arts and Sciences, Psychology Department of Psychology Morgantown West Virginia University.

[58] Logan M.S. \& Ganster D.C. (2007). The effects of empowerment on attitudes and performance: The role of social support and empowerment beliefs. Journal of Management Studies, 44 (8), 1523-1551.

[59] Dvir, T. \& Shamir, B. (2003). Follower development characteristics as predicting transformational leadership: a longitudinal field study. Leadership Quarterly, 14, 327344.

[60] Pillai, R. \& Williams, E. (2004). Transformational leadership, self-efficacy, group cohesiveness, commitment, and performance. Journal of Organizational Change Management, 17, 144-159.

[61] Menon, S.T. (1995). Employee Empowerment: Definition, Measurement and Construct Validation. McGill University, Canada.

[62] Deci, E. L. \& Ryan, R. M. (1985). Intrinsic motivation and self-determination in human behavior. New York. U.S.A.

[63] Ryan, R. M., \& Frederick, C. (1997). On Energy, Personality, and Health: Subjective Vitality as a Dynamic Reflection of Well-Being. Journal of Personality, 65(3), 529-565.

[64] Constantine, M. G., \& Sue, D.W. (2006). Factors contributing to optimal human functioning in people of color in the United States. The Counseling Psychologist, $34,228-244$.

[65] Lang, J.G., Muñoz, R.F., Bernal, G., \& Sorensen, J.L. (1982). Quality of life and psychological well-being in a bicultural Latino community. Hispanic Journal of Behavioral Sciences, 4, 433-450. 
[66] Ryff, C. D. \& Singer, B. (2002). From social structure to biology: integrative science in pursuit of human health and well-being. In Handbook of positive psychology (ed. C. R.Snyder \& S. J. Lopez), pp. 541-555. Oxford University Press, New York.

[67] Mahon, N.E., \& Yarcheski, A. (2001). Social support and well-being in early adolescents: The role of mediating variables. Clinical Nursing Research, 10 (2), 163-181.

[68] Gençöz T., \& Özlale Y. (2004). Direct and indirect effects of social support on psychological well-being. Social Behavior and Personality, 32(5), 449-458.

[69] Tofi, T., Flett, R., \& Timutimu-Thorpe, H. (1996). Problems faced by Pacific Island students at university in New Zealand: Some effects on academic performance and psychological wellbeing. New Zealand Journal of Educational Studies, 31(1), 51-59.

[70] Mathieu, J. E., \& Taylor, S. R. (2006). Clarifying conditions and decision points for mediational type inferences in organizational behavior. Journal of Organizational Behavior, 27(8), 1031-1056.

[71] House, R.J. \& Howell, J.M. (1992). Personality and charismatic leadership. Leadership Quarterly, 3(2), 81-108.

[72] House, J.S. (1981). Work Stress and Social Support. Addison-Wesley.

[73] Gardenhour, C. (2008). Teachers' perceptions of empowerment in their work environments as measured by the psychological empowerment instrument. Unpublished Doctoral Thesis, Faculty of the Department of Educational Leadership and Policy Analysis, East Tennessee State University.

[74] Bragger, J. D., Rodriguez-Srednicki, O., Kutcher, E. J., Indovino, L., \& Rosner, E. (2005). Work-family, workfamily culture and organizational citizenship behavior among teachers. Journal of Business and Psychology, 20, 303-324.

[75] Gönen, E., Hablemitoğlu, Ş., \& Özmete, E. (2004). Akademisyen kadınlar. Toplumsal Dönüşüm Publishing, İstanbul.

[76] Antonucci, T. C. (2001). Social relations: An examination of social networks, social support and sense of control. In J. E. Birren \& K. W. Schaie (Eds.), Handbook of the psychology of aging (5th Edition, pp. 427-453). Academic Press, New York.

[77] Felsten, G., \& Wilcox, K. (1992). Influences of stress and situation-specific mastery beliefs and satisfaction with social support on well-being and academic performance. Psychological Reports, 70(1), 291-303.

[78] Wright, B. E. (2001). Public-sector work motivation: A review of the current literature and a revised conceptual model. Journal of Public Administration Research and Theory, 11, 559.

[79] Short, P. \& Johnson, P. (1994). Exploring the links among teacher empowerment, leader power, and conflict. Education, 114, 581-592.

[80] Short, P. M. (1994). Defining teacher empowerment. Education, 114(4), 488-492.
[81] Ercan, S.N. (2009). Effects of work-family; family-work conflicts, self-construal, perceived managerial support and stress on employees' self-rated performance. Unpublished Doctoral Thesis, Social Sciences Institute, Department of Organizational Behavior, Marmara University.

[82] Spreitzer, G. M. \& Quinn, R. E. (2001). A company of leaders: Five disciplines for unleashing the power in your workplace. Jossey-Bass, San Francisco.

[83] Schwarzer, R. (Ed.). (1992). Self-efficacy: Thought control of action. Washington,DC: Hemisphere.

[84] Schwarzer, R. \& Jerusalem, M. (1995). Generalized selfefficacy scale. In J. Weinman, S. Wright, \& M. Johnston (Eds.), Measures in health psychology: A user's portfolio. Causal and control beliefs (pp. 35-37). Windsor, United Kingdom.

[85] Yesilay, A., Schwarzer, R., \& Jerusalem, M. (1997). Turkish adaptation of the general perceived self-efficacy scale. http://userpage.fuberlin.de/ health/ turk.htm, [22.04.2010]

[86] Warr, P. B. (1990). Decision latitude, job demands, and employee well-being. Work \& Stress, 4, 285-294.

[87] Grandey, A. A. (1999). The effects of emotional labor: employee attitudes, stress and performance. Published Doctoral Dissertation, Colorado State University.

[88] Ünler Öz, E. (2007). Duygusal emek davranışlarının çalışanların iş sonuçlarına etkisi. Beta Publishing, İstanbul.

[89] Baron, R.M. \& Kenny, D.A. (1986). The moderatormediator variable distinction in social psychological research: conceptual, strategic, and statistical considerations. Journal of Personality and Social Psychology, 51(6), 1173-1182.

[90] Sharma, S. (1996). Applied multivariate techniques. John Wiley, New York.

[91] Siegall, M. \& Gardner, S. (2000). Contextual factors of psychological empowerment. Personnel Review, 29(6), 703-722.

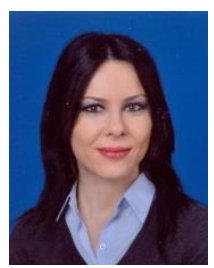

\section{SEÇIL BAL TAŞTAN} secilbal@yahoo.com

Seçil Bal Taştan is a Lecturer Doctor working in management and organization department. She has a doctorate degree of Organizational Behavior. Her interests are in management and organization, organizational behavior, organizational psychology, and human resources management. She has authored a number of academic research studies in academic journals and conferences on these subjects. 